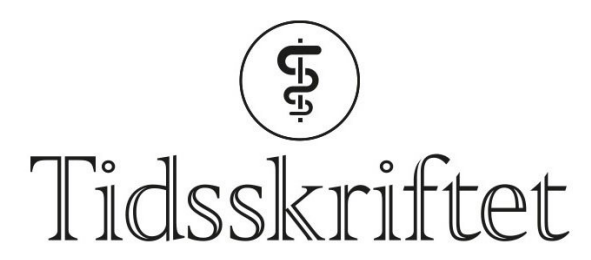

DEN NORSKE LEGEFORENING

\title{
Pulmonal arteriovenøs malformasjon
}

MEDISINEN I BILDER

\section{LINN ASSKILDT}

E-post: linass-vvhf@vestreviken.no

Linn Asskildt er lege i spesialisering i radiologi og jobbet tidligere ved Bildediagnostisk avdeling, Drammen sykehus.

Forfatter har fylt ut ICMJE-skjemaet og oppgir ingen interessekonflikter.

\section{SILJE WETTING}

Silje Wetting er spesialist i radiologi og overlege ved Bildediagnostisk avdeling, Drammen sykehus. Forfatter har fylt ut ICMJE-skjemaet og oppgir ingen interessekonflikter

\section{ANDERS FJELD}

Anders Fjeld er spesialist i indremedisin og i lungemedisin og er overlege ved Medisinsk avdeling, Drammen sykehus.

Forfatter har fylt ut ICMJE-skjemaet og oppgir ingen interessekonflikter.

Det 3D-rekonstruerte CT-bildet viser her komplekse pulmonale arteriovenøse malformasjoner - en unormal kommunikasjon mellom pulmonalarterier og pulmonalvener - hos en mann i zo-årene som ble innlagt grunnet akutt dyspné.

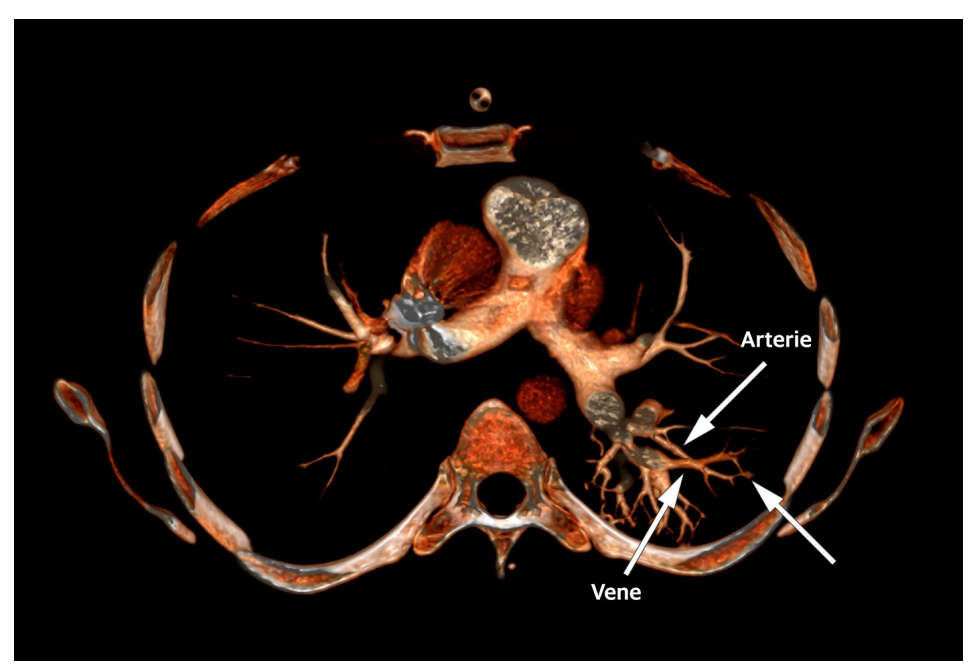

Tilstanden er assosiert med signifikant morbiditet og mortalitet i form av hjerneslag og cerebrale abscesser som kan forekomme hos opptil $70 \%$ av dem som har komplekse malformasjoner (1).

Dette er en sjelden tilstand. Estimert prevalens er ca. 38 per 100 ooo (2). Tilstanden er ofte assosiert med den dominant arvelige sykdommen Osler-Weber-Rendus syndrom, hvor mer enn 1 av 4 har pulmonale arteriovenøse malformasjoner (1). Vår pasient hadde ingen symptomer eller familieanamnese som tydet på dette syndromet. 
Pasienten var tidligere operert for en intrakranial abscess, men ellers frisk. Symptomene ved innkomst var dyspné, svimmelhet, tåkesyn og hodepine. Oksygenmetning på romluft var ca. $80 \%$, for øvrig normale verdier, blodprøver og funn ved klinisk undersøkelse.

Grunnet mistanke om residiv av abscess ble det rekvirert CT caput, hvor det ble påvist postoperative forandringer. Det ble utført CT thorax med lungeemboliprotokoll til tross for negativ D-dimer. Denne påviste flere dilaterte arterier og vener på subsegmentnivå og lengre perifert dorsalt i venstre overlapp og underlapp. Flere steder var det kommunikasjon mellom distale kargrener på arterie- og venesiden. Funnene var forenlig med pulmonale arteriovenøse malformasjoner.

Pasienten ble henvist til Rikshospitalet, hvor det ble gjennomført kilereseksjon. Et behandlingsalternativ er coiling. Valg av behandling styres av angioarkitektur og vurdering av strålebelastning.

Pulmonale arteriovenøse malformasjoner påvises oftest ved screening av asymptomatiske pasienter med familieanamnese for Oslers syndrom eller som et tilfeldig funn ved radiologiske undersøkelser (1). Tilstanden bør vurderes som differensialdiagnose ved epistaxis, uforklarlig dyspné og hypoksemi. I tillegg må pasienter med hjerneslag eller hjerneabscess som har fått påvist malformasjoner på CT eller lungenoduli på røntgen thorax, vurderes for tilstanden (1).

Store malformasjoner kan av og til påvises ved røntgen thorax. CT, MR og kontrast-ekko er likevel best egnet til deteksjon og oppfølging av malformasjonene (1).

LITTERATUR:

1. Gossage JR, Mandel J, Finlay G. Pulmonary arteriovenous malformations. https://www.uptodate.com/contents/pulmonary-arteriovenous-malformations-clinical-features-and-d iagnostic-evaluation-in-adults (18.6.2018).

2. Nakayama M, Nawa T, Chonan T et al. Prevalence of pulmonary arteriovenous malformations as estimated by low-dose thoracic CT screening. Intern Med 2012; 51:1677 - 81. [PubMed][CrossRef]

Publisert: 31. august 2018. Tidsskr Nor Legeforen. DOI: 10.4045/tidsskr.18.0106 Mottatt 29.6.2018, første revisjon innsendt 11.6.2018, godkjent 18.6.2018.

(C) Tidsskrift for Den norske legeforening 2020. Lastet ned fra tidsskriftet.no 